\title{
Democracia Pragmática: Pressupostos de uma Teoria Normativa Empiricamente Orientada*
}

\section{Thamy Pogrebinschi}

Professora e pesquisadora do Instituto de Estudos Sociais e Políticos (IESP), da Universidade do Estado do Rio de Janeiro (UERJ). E-mail: thamy@iesp.uerj.br

\begin{abstract}
cisão existente na ciência política entre, de um lado, os que trabaA lham com teoria e, de outro, aqueles que se dedicam aos estudos empíricos sobre as instituições é um fato que se tornou notório desde a institucionalização da disciplina, em particular no Brasil (Amorim Neto e Santos, 2005). O alijamento entre as abordagens conceituais da política e as análises empíricas de suas instituições impõe indubitáveis limites ao desenvolvimento interno de cada uma destas subdivisões disciplinares e, sobretudo, implica a ausência de uma cooperação essencial à solução dos dilemas políticos e dos impasses sociais do mundo contemporâneo. No caso específico da teoria política, a ausência de diálogo com a empiria parece ser ainda mais nociva, pois, a despeito do inegável valor intrínseco do tratamento filosófico e histórico da política, uma significativa parcela das teorizações recentes parece estar cada vez mais apartada da experiência - única instância que permitiria validá-las, aplicá-las e refleti-las na realidade concreta, de modo a não permitir que sejam reduzidas unicamente ao seu valor heurístico.
\end{abstract}

As causas do divórcio entre a teoria política contemporânea e os estudos empíricos sobre as instituições políticas não podem ser reduzidas

\footnotetext{
* Agradeço ao parecerista anônimo de DADOS pelos valiosos comentários e construtivas críticas que me forçaram a uma longa reflexão sobre este texto e um ainda mais longo processo de reescrita que culminou em importantes reformulações nesta versão final. Agradeço também a Leonardo Avritzer pelo fundamental incentivo para que eu publicasse este artigo e, mais importante, não deixasse de acreditar nas ideias nele expressas.

DADOS - Revista de Ciências Sociais, Rio de Janeiro, vol. 53, nº3, 2010, pp. 657 a 693.
} 
a motivos de ordem meramente metodológica ou epistemológica. Contudo, é possível supor que, nas últimas três décadas, tais causas podem ser tributadas, sem prejuízo de outras explicações, ao caráter eminentemente normativo assumido por significativa parte da teoria política. Este normativismo característico de parcela da produção teórica recente sobre a política - em particular, aquela influenciada pelo procedimentalismo de John Rawls e Jürgen Habermas - a afasta cada vez mais da realidade, ao sacrificar até mesmo suas usuais ferramentas de abstração conceitual, especulação filosófica e investigação histórica em nome de ideais reguladores que prescrevem, muitas vezes, um "dever ser" impotente diante da complexidade e da contingência que marcam a sociedade contemporânea.

Os limites de tais abordagens normativas tornam-se evidentes quando se atenta para o tratamento dado ao tema da democracia. Marcadas pelos impasses da democracia representativa, que se aperfeiçoa em tensão permanente com a natureza supostamente irrepresentável da soberania popular, as teorias normativas da democracia dão visíveis sinais de desgaste na medida em que lançam mão de propostas fadadas a fracassar na primeira tentativa de se submeter ao teste da realidade. Sem encontrar soluções factíveis para resolver os paradoxos que cercam a prática da representação política, a teoria democrática não se mostra ainda capaz de superar alguns dos dilemas deixados em aberto pelo pensamento moderno diante das instituições políticas do mundo contemporâneo.

Nas últimas décadas, são crescentes os investimentos da teoria política em projetos normativos que tencionam superar a democracia representativa por meio de concepções de democracia participativa ou deliberativa. Os limites de tais projetos expõem-se, contudo, ao serem os mesmos apresentados como alternativas diante de uma suposta crise da democracia representativa sem que isso seja precedido por uma investigação da natureza da própria representação política e por uma análise dos motivos que embasam a suposição de que a mesma encontra-se efetivamente em crise.

Entre os riscos apresentados pelas abordagens normativas encontra-se, portanto, o de fazer a teoria democrática contemporânea dirigir seus esforços para a elaboração de novas concepções de democracia sem, antes, buscar seus fundamentos na própria democracia representativa. Uma abordagem dialética do problema permite revelar que su- 
postas contradições - como aquelas a parentemente existentes entre representação e participação ou representação e deliberação - apenas podem ser superadas pelo aprofundamento da relação de oposição que as constituem. Uma concepção de democracia participativa ou deliberativa não se constituirá em um modelo alternativo factível e viável à democracia representativa simplesmente buscando substituir, por meio de proposições normativas, a representação pela participação e/ou deliberação.

Este artigo parte da premissa de que a reflexão contemporânea sobre a democracia não deve se esgotar na falsa dicotomia entre representação e participação, tampouco no falso dualismo entre representação e deliberação. Falsos, uma vez que representação e participação ou representação e deliberação, se concebidas como oposições verdadeiras, devem apresentar-se na forma de uma contradição passível de ser superada de modo dialético. Dialética esta que falta à teoria democrática contemporânea, incapaz de conferir ao normativismo um caráter materialista que lhe permita superar dualismos que são característicos da modernidade política.

Pensar dialeticamente a democracia implica reconhecer que as alternativas possíveis são mais amplas e numerosas do que a falsa dicotomia entre democracia representativa, de um lado, e democracia participativa ou deliberativa, de outro, faz supor. Há muitas possibilidades ainda não exploradas, mesmo do ponto de vista normativo, justamente pela relutância da teoria democrática em se valer do aporte da realidade empírica a fim de testar suas premissas, alargar seus conceitos, revalidar seus significados e ampliar seus horizontes.

Este artigo propõe-se a introduzir as linhas gerais de um conceito que busca lidar dialeticamente com as supostas contradições existentes entre representação e participação, e representação e deliberação: a democracia pragmática. Tendo por base pressupostos filosóficos do pragmatismo, meu objetivo é apresentar a democracia pragmática como um conceito normativo que não se priva do diálogo com as análises empíricas que permitem compreender a lógica das instituições representativas e o papel que vem assumindo as práticas participativas e deliberativas. Em outras palavras, com o conceito de democracia pragmática almejo construir uma alternativa dialética às falsas contradições que cercam o debate contemporâneo sobre a democracia, com o 
ensejo de apresentar uma abordagem sobre a mesma que seja, a um só tempo, formulada normativamente e orientada empiricamente.

\section{UM CONCEITO NORMATIVO E UMA ABORDAGEM PRAGMÁTICA}

O que chamo de democracia pragmática envolve tanto um conceito normativo de democracia como uma abordagem analítica para a sua compreensão e avaliação, o que, a despeito de encontrar inspiração no pragmatismo, não traduz nenhuma concepção particular de democracia endossada pelos pensadores usualmente associados a esta tradição filosófica. Entendo por democracia uma mediação entre Estado e sociedade civil, e suponho ser o pragmatismo uma ferramenta teórica profícua para explicar o tipo de relação entre Estado e sociedade civil que se verifica no mundo contemporâneo, e em particular no Brasil. Se a democracia é uma forma de mediação entre Estado e sociedade civil, o que entendo por democracia pragmática é, normativamente, uma mediação que busca superar a contradição entre Estado e sociedade civil por meio da supressão do falso dualismo entre representação, de um lado, e participação e deliberação, de outro.

Mais especificamente, entendo por democracia um conjunto aberto de instituições, experiências e práticas que possuem por escopo a mediação entre Estado e sociedade civil. O desempenho da democracia, neste sentido, varia de acordo com o desempenho de tal mediação. O sucesso da mediação, por sua vez, mede-se pelo sucesso na superação do antagonismo entre Estado e sociedade civil. Quanto mais uma determinada instituição, experiência ou prática logra aproximar Estado e sociedade civil, maior é a sua capacidade de promover a democracia. Em outras palavras, quanto menor for a separação estrutural e a diferenciação funcional entre Estado e sociedade civil, maior será o grau de democracia de um determinado regime político.

O caráter irrefutavelmente normativo do conceito de democracia pragmática revela-se também em seu escopo de partir de uma crítica ao caráter normativo das teorizações contemporâneas sobre democracia deliberativa e participativa com o fito de defender uma concepção ampliada de representação política que seja nutrida por análises institucionais de cunho empírico. Assim, ao passo que o conceito de democracia pragmática é declaradamente normativo em seu escopo, isso não é verdadeiro em relação ao seu alcance. Por mais que aquilo que chamo de democracia pragmática, em sua gênese conceitual, possa inevitavel- 
mente servir de referencial para outras teorizações igualmente normativas sobre a democracia, isso não oblitera o seu uso enquanto mecanismo analítico passível de ser empregado na descrição do comportamento das instituições e práticas políticas existentes, em particular no Brasil.

Para que restem claros o escopo normativo e o alcance analítico do conceito de democracia pragmática, passo a mencionar alguns de seus principais pressupostos e aplicações. Em primeiro lugar, o conceito de democracia pragmática (1) provê uma alternativa dialética ao falso dualismo existente entre representação e participação/deliberação ou, em outras palavras, entre democracia representativa e outras formas supostamente não representativas de democracia. Em segundo lugar, a democracia pragmática (2) propicia uma abordagem sobre a democracia que seja, a um só tempo, formulada normativamente e orientada empiricamente.

Destes dois pressupostos principais derivam algumas aplicações secundárias. Assim, em terceiro lugar, o conceito de democracia pragmática propõe-se a (3) resgatar e fortalecer o conceito de representação política, a fim de prover-lhe um significado ampliado que possibilite, entre outras coisas: (3.1) abarcar dentro de si princípios participativos e deliberativos, assim como práticas e experiências concretas que derivam destas duas abordagens da democracia; (3.2) estender a noção de representação política não apenas aos espaços e atores da sociedade civil, mas também a instituições não majoritárias que possam justificada e legitimamente participar do processo político-decisório; e (3.3) redefinir a noção de delegação que se encontra na base do conceito moderno de representação política, a fim de prover de legitimidade democrática a defesa da representação política ampliada.

Em quarto lugar, o conceito de democracia pragmática tem por pressuposto (4) fornecer um referencial heurístico adequado ao estudo da democracia contemporânea, em particular a brasileira. A fim de cumprir tal pressuposto, encontram-se entre suas aplicações: (4.1) prover um marco teórico para a compreensão de fenômenos empíricos, tais como (4.1.1) a crescente institucionalização de experiências participativas como as conferências e os conselhos nacionais e seu impacto na formulação de políticas públicas pelo Poder Executivo e na produção legal do Poder Legislativo, de modo a examinar se participação e deliberação podem fortalecer a representação; e (4.1.2) o crescente papel políti- 
co do Supremo Tribunal Federal e seu impacto no processo legislativo, de modo a verificar se a chamada judicialização tem o condão de fortalecer a representação.

Em quinto lugar, o conceito de democracia pragmática tem por pressuposto (5) estabelecer um diálogo entre a teoria política e as análises empíricas das instituições democráticas. Com o pressuposto de fazer cooperarem teoria e empiria, a democracia pragmática (5.1) defende o normativismo materialista como uma perspectiva epistemológica propícia a promover uma conciliação entre a abordagem empírica das análises institucionais e a abordagem normativa da teoria política contemporânea. É desse modo que o desenvolvimento do conceito de democracia pragmática permite (5.2) apresentar aportes propositivos à teoria democrática, em geral, e à teoria da representação política, em particular, que, simultaneamente, possuam como ponto de partida e ponto de chegada questões concretas encontradas na prática da democracia contemporânea.

O que chamo de democracia pragmática oferece-se, assim, a um só tempo como um conceito normativo e uma abordagem analítica. Enquanto conceito normativo, a democracia pragmática busca explorar possibilidades de fortalecimento da democracia por meio de uma compreensão ampliada da representação política que, entre outros aspectos a serem mencionados neste artigo, a torne mais permeável às práticas participativas e deliberativas. Enquanto abordagem analítica, a democracia pragmática encontra no pragmatismo fonte de interpretações mais realistas e menos idealizadas sobre o modus operandi da democracia contemporânea e de suas instituições. Nesse sentido, desdobra-se em três dimensões.

Primeiro, em uma dimensão epistemológica, que consiste na identificação dos elementos e características definidoras da representação política, de seus pressupostos, de sua natureza conceitual, de sua gênese constitutiva, de sua formação histórica, de seus significados empíricos e normativos, de suas formas e modalidades de aplicação, de seus padrões de observação e, por fim, de suas condições de realização.

Segundo, em uma dimensão analítica, que implica a compatibilização entre os significados normativos imputados à representação política $\mathrm{e}$ a viabilidade empírica de sua realização, no teste das consequências engendradas pelos arranjos institucionais que suportam os postulados normativos, na identificação dos valores e ideais que se buscam pre- 
servar por meio das instituições e práticas representativas existentes, e na identificação dos valores e ideais cujos custos de violação seriam considerados aceitáveis uma vez endossadas propostas de reforma política que visem tornar mais efetiva a representação por meio de ajustes funcionais e estruturais em suas instituições.

Terceiro, em uma dimensão crítica, que permite assumir os limites evidenciados por análises sobre como as instituições representativas funcionam na prática (e sobre como seus agentes comportam-se empiricamente) enquanto pressupostos para a reformulação dos postulados normativos que orientam as teorias da representação política - além de tomar esses mesmos postulados normativos como critérios vinculantes a orientar a concepção, formulação e execução de toda e qualquer proposta de reestruturação das instituições políticas.

Essas três dimensões sugerem, por sua vez, o resgate de três características do pragmatismo: reflexividade, praticalismo e experimentalismo. Cada uma dessas características, conforme argumentarei nas próximas páginas, serve de orientação a uma das três dimensões por meio das quais uma abordagem pragmática da democracia deve ser realizada.

\begin{tabular}{|c|c|}
\hline Dimensão & Abordagem \\
\hline Epistemológica & Reflexividade \\
\hline Analítica & Praticalismo \\
\hline Crítica & Experimentalismo \\
\hline
\end{tabular}

\section{A Dimensão Epistemológica: Reflexividade}

A dimensão epistemológica do conceito de democracia pragmática orienta-se pela ideia de reflexividade. Por reflexividade entendo a adoção de uma perspectiva antifundacionalista que implica, simultaneamente, falibilismo, revisabilidade e responsividade. Uma vez que esta dimensão preocupa-se prioritariamente com questões de natureza epistemológica relativas ao desenvolvimento do conceito de democracia pragmática de uma forma geral, e da ampliação do conceito de representação política de forma mais particular, a reflexividade se manifesta através de um exercício permanente de mutação conceitual. Isso implica a adoção de uma postura menos dogmática em relação aos conceitos e, especialmente, em relação aos seus significados. 
Assumindo a falibilidade dos conceitos e, sobretudo, a relatividade de seus significados diante de contextos dinâmicos e mutáveis, a abordagem pragmática da democracia abre-se para um reexame constante de seu núcleo semântico, bem como dos pressupostos nos quais provisoriamente se alicerça. Disso decorre o enorme potencial responsivo da democracia pragmática, que se revela como uma textura aberta na qual os conceitos encontram-se permanentemente sujeitos à revisão e seus significados sujeitos à alteração. Essa perspectiva antifundacionalista afigura-se como uma estratégia valiosa diante da contingência e da complexidade do mundo contemporâneo.

A fim de adaptar-se a contextos fortemente contingentes e explicar sociedades cada vez mais complexas, a democracia requer uma abordagem realista e não essencialista, que se assuma como falível e não se apoie em dogmatismos, e que possua fundamentos tão provisórios quanto a sua capacidade de responder a eles através de uma revisão consistente de seus próprios significados, bem como dos valores e ideais que lhes servem de sustentação. Em termos concretos, a dimensão epistemológica da democracia pragmática, ao implicar uma atitude reflexiva, possibilita que a noção de democracia representativa se fortaleça, por exemplo, por meio de uma revisão do significado do conceito de representação política.

A democracia representativa, após ter alguns de seus pressupostos desafiados pela crítica da teoria da escolha social (Riker, 1982; Mackie, 2003), viu-se confrontada pelos modelos participativos (Pateman, 1970; Mansbridge, 1980; Barber, 1984; Fung, 2004; Avritzer 2002) e deliberativos (Cohen, 1989; Fishkin, 1991; Habermas, 1995; Gutmann, 1996; Bohman, 1996; Dryzek, 2000), o que tornou imperativa a necessidade de que fosse conceitualmente repensada a fim de converter seus supostos vícios em fontes renovadas de virtude e fazer de suas eventuais fraquezas a fonte de renovação de suas forças.

A ampliação do conteúdo semântico do conceito de representação política revela-se necessária a fim de que o mesmo possa responder seja aos paradoxos que cercam a prática dos sistemas eleitorais e dos partidos políticos, seja aos dilemas colocados pela crescente atividade política de instituições não majoritárias e de atores não eleitos, e seja, principalmente, aos desafios impostos pelas abundantes experiências participativas e deliberativas que vêm sendo efetivamente levadas a cabo pela sociedade civil ao redor do mundo (Mansbridge, 2003; Urbinati, 
2006; Gurza Lavalle 2006; Castiglione e Warren, 2006; Avritzer, 2007; Saward, 2009).

Em termos concretos, a revisão conceitual da representação política que se encontra na base do desenvolvimento da democracia pragmática implica uma atualização de alguns dos conteúdos semânticos historicamente associados a tal conceito. De início, a defesa de uma noção ampliada de representação política depende da atualização semântica: a) do fundamento da representação, a delegação; b) de seu corolário e condição de validade, a revogação; c) de sua principal condição de legitimidade, a eleição. Tratarei agora do fundamento da representação política, deixando para discutir a legitimidade e a validade da representação ampliada adiante, quando tratarei do praticalismo e do experimentalismo endossados pela democracia pragmática.

Uma vez que a ideia de delegação política que se encontra no cerne do conceito e da prática da representação possa ser revista, ampliada e adaptada tendo em vista os paradoxos, dilemas e desafios mencionados anteriormente, talvez seja possível lidar de forma eficaz com alguns dos problemas de legitimidade e accountability que marcam a democracia representativa contemporânea, fortalecendo-a diante daqueles que se mostram ávidos para superá-la.

De um modo geral, a teoria democrática pouco avançou em relação ao modelo hobbesiano de autorização, que alicerça, pelo menos desde o século XVII, a representação política sobre uma base contratualista. Uma das razões pelas quais a teoria democrática não avançou significativamente na compreensão da representação como algo além do "agir pelo outro" facultado pela noção de autorização talvez possa em parte ser tributada a sua falta de diálogo com a ciência política de cunho empírico. Esta vem, por exemplo, desenvolvendo ao longo dos últimos anos uma sólida teoria da delegação centrada em modelos que explicam a relação entre principal e agente em momentos pré e póseleitorais (delegação do eleitor ao representante) e em espaços intra e interinstitucionais (delegação do Executivo ao Legislativo, e viceversa). Talvez pelo simples preconceito contra a escola da escolha racional, a teoria democrática contemporânea passa ao largo desses estudos (apenas para citar alguns: Kiewiet e McCubbins, 1991; Lupia e McCubbins, 1998; Epstein e O'Halloran, 1999; Strom, Müller e Bergman, 2003), perdendo a chance de converter ricas análises em novos postulados a partir dos quais o fundamento da representação política 
possa ser explicado diante das condições reais do mundo contemporâneo, desprendendo-se de seu vínculo anacrônico com a teoria da soberania da política moderna.

Beneficiando-se de uma revigorada teoria da delegação, a democracia pragmática clama por fazer com que a representação política transcenda o momento eleitoral e o espaço das instituições políticas tradicionais, aproximando-se de uma concepção de governança que perpasse os limites dos mandatos eletivos e alcance, além das práticas participativas e deliberativas da sociedade civil, as instituições não majoritárias do Estado. Uma vez que essas possam ser encaradas como instituições efetivamente representativas, estendendo-se às mesmas o liame representacional por meio de uma delegação política originária de fontes tão diversificadas quanto o eleitor, a constituição, o Executivo ou o próprio Legislativo, pode-se revisar o conteúdo semântico da representação de modo que a mesma implique um agir com o outro que supere a moderna noção de autorização com a qual uma significativa parte da teoria política ainda trabalha.

A defesa da democracia representativa em paralelo às abordagens participativas e deliberativas, por mais minoritária que se apresente contemporaneamente na teoria política, aponta justamente para a necessidade de ressignificar conceitos como os de representação e democracia. Tal reconsideração semântica possibilitaria, por exemplo, a percepção de que: 1) a representação política não é meramente uma alternativa second best diante da impossibilidade de uma democracia direta, e 2) a representação política não se encontra em crise, ao contrário do que muitos gostam de supor e alardear.

O argumento de que a representação política não é meramente uma alternativa second best diante da impossibilidade de uma democracia direta pode ser facilmente deduzido do resgate da democracia representativa promovido recentemente pelas obras de Urbinati (2006) e Manin (1996). Embora adotem perspectivas diversas, ambos os autores questionam o vínculo entre democracia e representação, mostrando que o nexo assumido historicamente pelos dois conceitos não é trivial. Mais relevante do que isso é, para os propósitos de uma democracia pragmática, a constatação propiciada por tais obras no sentido de que muitas das acusações que se fazem hodiernamente à democracia representativa derivam de problemas de natureza epistemológica que apontam 
para a necessidade de atualização do significado dos conceitos de representação política e de democracia representativa.

Manin argumenta que a forma moderna de democracia permanece de certo modo imutável desde o século XVIII. Assim, o que se designa hoje de democracia representativa encontra suas origens em instituições concebidas naquele século e que teriam sido universalizadas após as três revoluções modernas (a inglesa, a americana e a francesa). $\mathrm{O}$ que faculta a constatação da 'imutabilidade' da forma da democracia é a identificação do governo representativo com um conjunto de princípios observados historicamente em todos os governos nomeados como representativos. Tais princípios (que se subsumem em quatro: os governantes são designados por eleições realizadas em intervalos regulares; os governantes conservam, em suas decisões, certa independência em face das vontades dos eleitores; os governados podem exprimir suas opiniões e suas vontades políticas sem que as mesmas sejam submetidas ao controle dos governantes; as decisões públicas são submetidas à discussão) seriam traduzidos por escolhas institucionais feitas pelos fundadores do governo representativo, as quais não teriam sido jamais efetivamente questionadas desde a sua concepção.

Mesmo grandes inovações históricas - como a adoção do sufrágio universal e o advento dos partidos de massa - não teriam afetado, de acordo com Manin, os princípios fundamentais e as escolhas institucionais originais que permanecem ainda em vigor nos regimes que chamamos hoje de democracia representativa. Chama ainda atenção o autor, como também o fez Rosanvallon (1998), para o fato de que tais instituições representativas não tenham sido percebidas no momento de sua concepção como uma variedade da democracia. Ou seja, os atuais regimes políticos se originariam de uma forma de governo - o governo representativo - que seus fundadores opunham à democracia. Assim resulta a questão de saber por que um governo organizado segundo os princípios representativos era considerado no fim do século XVIII como algo inteiramente distinto da democracia e hoje em dia é tido como a principal de suas formas.

Uma vez que o governo representativo teria se constituído historicamente em oposição à democracia e vice-versa, é razoável pressupor que os dois conceitos não compartilham originalmente o mesmo conteúdo semântico, e que as associações equivocadas que se lhe atribuem ao longo dos últimos séculos respondem pela também equivocada compreensão contemporânea do governo representativo como não de- 
mocrático, da representação política como uma alternativa second best, e das instituições representativas como imersas em uma crise. Manin corrobora este diagnóstico, mostrando que as incertezas e imprecisões da terminologia contemporânea indicam que não sabemos exatamente o que aproxima e o que distingue o governo representativo da democracia.

Tão importante quanto isso, Manin esclarece que aquilo que se chama hoje de crise da representação política apresenta-se de modo diferente se percebermos que o governo representativo foi concebido em oposição explícita à ideia de democracia (compreendida em seu sentido grego, enquanto governo do povo pelo povo) e que seus dispositivos institucionais centrais jamais se alteraram desde que foram concebidos. Não haveria assim, portanto, de falar-se em crise, mas apenas admitir-se que o governo representativo assumiu uma nova forma.

Esta nova forma, que acredito não ser aquela descrita por Manin sob o conceito de "democracia do público", certamente é uma desafiada pelas práticas e experiências participativas e deliberativas que proliferam não apenas entre os livros enfileirados nas prateleiras da teoria democrática, mas também na prática dos governos democráticos ao redor do mundo, e especialmente na América Latina. Daí que tomar os seus conceitos centrais como falíveis e seus significados como revisáveis torna a democracia representativa mais responsiva tanto aos dilemas teóricos que a cercam quanto aos desafios práticos que a colocam à prova.

É este o tipo de postura reflexiva - que toma os conceitos como falíveis e seus significados como revisáveis - endossada pela dimensão epistemológica da democracia pragmática. Uma revisão do significado do conceito de representação política à luz das condições materiais do presente possibilita que a democracia representativa se fortaleça ao assumir novos sentidos, assim como a reafirmação de seus postulados normativos permite que a mesma abra-se para novas configurações institucionais. É desse modo que as instituições representativas devem engendrar em si mesmas os arranjos participativos e deliberativos que possibilitem a sua própria superação.

\section{A Dimensão Analítica: Praticalismo}

A dimensão analítica da democracia pragmática orienta-se pelo praticalismo. Por praticalismo entendo a adoção de uma postura prática que 
implica consequencialismo, futuridade e um entendimento bastante particular da relação entre meios e fins. Praticalismo não se confunde com instrumentalismo, e muito menos deve ser associado ao utilitarismo, conforme restará claro nas próximas páginas.

Aplicado à dimensão analítica da teoria da democracia pragmática, o consequencialismo propicia uma compreensão e uma interpretação específicas do comportamento das instituições e dos atores políticos. Para além de explicar o recurso a ações, escolhas e decisões estratégicas que podem todavia se beneficiar de uma metodologia utilitarista, $\mathrm{o}$ consequencialismo oriundo do pragmatismo consiste em um exercício permanente de antecipação das consequências da ação como forma de prover significação às mesmas. Não se trata meramente de supor que atores políticos ajam de forma racional tendo em vista a realização de seus interesses ou a maximização da utilidade individual e assim explicar, com base no cálculo das consequências, o seu comportamento. Trata-se, sim, de compreender como o consequencialismo pode operar como forma de justificação, avaliação, validade e legitimidade da democracia.

O teste pragmatista das consequências - que, cabe desde logo ressaltar, não objetiva eleger a "melhor" consequência, tampouco a "mais útil", mas sim aquela que se revela mais adequada ao suprimento das demandas de um contexto específico no qual se dá a ação - permite deslocar as questões de justificação, avaliação e legitimidade da democracia de um plano ex ante para um ex post. Isto é, os procedimentos, regras e valores a partir dos quais usualmente se mensura a democracia cedem lugar, por meio da abordagem praticalista, aos efeitos e consequências percebidos no plano concreto. Uma vez que consequências obtidas apresentam efeitos aceitáveis e desejáveis - a despeito do procedimento, regra ou valor que as ensejou - elas podem servir de parâmetro adequado de mensuração para a democracia. A adoção dessa abordagem permite que se avance na análise do jogo político democrático que, muitas vezes, vê-se engessado por premissas, pressupostos e postulados que determinados contextos históricos uma vez forneceram à democracia e os quais são tomados como invioláveis e irrefutáveis a despeito de sua já comprovada incapacidade de responder aos resultados negativos que experimentam em sua prática contemporânea.

Em termos concretos, uma abordagem praticalista permite que se lide com os problemas de justificação, avaliação e legitimidade da demo- 
cracia não exclusivamente a partir das noções de eleição, regra da maioria e igualdade política, mas sim com base nas consequências engendradas pela atividade das instituições e dos atores políticos no mundo real. É a desejabilidade e a aceitabilidade de tais consequências que devem servir de parâmetro para mensurar a democracia e, assim, avaliá-la, justificá-la ou legitimá-la. São essas consequências, ademais, que permitem a identificação daquilo que é viável sob um ponto de vista empírico, permitindo, assim, que se alcance uma prática realista da democracia - e não uma versão idealizada da mesma que, ao desmentir seus fundamentos e pressupostos, acaba invariavelmente por alimentar o ceticismo e a descrença.

Ao deslocar-se a análise, portanto, dos fundamentos para os efeitos da democracia, desloca-se também das formas e soluções apriorísticas, principiológicas, normativas, transcendentais e contrafáticas para os fatos concretos que resultam como consequências que apenas podem ser mensuradas (e, portanto, significadas) em um momento posterior à ação que as enseja. É com a adoção desta postura prática que uma concepção pragmática da democracia busca reagir às teorias minimalistas (Schumpeter, 1942; Przeworski, 1999), procedurais (Dahl, 1997) e procedimentais (Habermas, 1989; Rawls, 1993) da democracia. É também com a adoção desta postura prática que almejo estender a compreensão da representação política para práticas participativas da sociedade civil e instituições não majoritárias do Estado, precisamente com base no caráter representativo que os mesmos podem assumir em função da desejabilidade, aceitabilidade e viabilidade das consequências engendradas por eles.

Além do consequencialismo, a abordagem praticalista da democracia pragmática se expressa por meio da futuridade. Uma das primeiras características do pragmatismo enunciadas por seu fundador, Charles $S$. Peirce (1905), na tentativa de defini-lo, a futuridade pode beneficiar a democracia com um caráter forward-looking, orientado para o futuro, dirigido à satisfação das demandas colocadas pelo presente, tendo em vista a realização de um futuro que se considere desejável. Este olhar para o futuro permite que a democracia seja abordada de uma forma menos presa a ideais e valores que pertencem a um passado e torne-se mais aberta e permeável a ideais e valores que explicam o momento presente e compõem o cenário de futuros possíveis que podem ainda ser desenhados e controlados. 
A futuridade pragmatista implica aceitar a democracia que temos a fim de transformá-la na democracia que queremos - o que me parece uma atitude mais defensável do que insistir em fazer caber as instituições e práticas políticas existentes no presente em molduras desenhadas no passado. $O$ futuro da democracia não se encontra nas deliberações da Ágora ateniense da Grécia antiga, não está inscrito nas normas constitucionais oriundas da Revolução Francesa, tampouco se encontra previsto de forma exaustiva nos procedimentos e instituições formulados pelos Federalistas norte-americanos. O futuro da democracia encontra-se nos fatos e nas ações que podem ser controlados justamente porque ainda não aconteceram. Ee isso que o método pragmatista de antecipação das consequências permite, provendo-se significados para objetos (sejam eles regras, procedimentos, decisões etc.) tendo em vista o seu futuro, e não o seu passado.

A futuridade permite, por conseguinte, passar de uma análise anacrônica da democracia em função do que ela foi ou do que se quis um dia que fosse para uma análise que parta de uma descrição realista e não idealizada de suas instituições e práticas a fim de converter o seu potencial presente em transformação futura. Fazer substituir a reverência ao passado e a deferência à tradição pela futuridade não significa, evidentemente, abraçar-se a proposições normativas ancoradas em pontos de partida hipotéticos ou contrafáticos. Ao contrário, a futuridade pragmatista possui relação direta com a factualidade que a informa, pois são os fatos do presente que determinam o significado que os mesmos possuem em um futuro que apenas no presente pode ser antecipado. O praticalismo permite, assim, converter normativismo em materialismo, dando sentido à futuridade através da factualidade.

Por fim, a abordagem prática suscitada pela dimensão analítica da democracia pragmática implica também um entendimento específico acerca da relação que devem assumir, na política, meios e fins. Quanto a este aspecto, Dewey, certamente o mais político dos primeiros pragmatistas, deixou grandes lições que muito importa serem hoje recuperadas. Dizia Dewey (1937), por exemplo, que, se a democracia tinha por fim a liberdade de todos, isso só poderia ser realizado por meios que concordassem com este fim, ou seja, meios liberais. De modo análogo, podemos supor que se a democracia tem como fim a igualdade social esta será realizada por meios com ela condizentes, ou seja, por meios socialistas e, portanto, não liberais. Mas os fatos revelam que isso nem sempre é verdadeiro, e que, por exemplo, tentativas de promover a 
igualdade por meios absoluta e irrestritamente igualitários podem, na prática, resultar em uma desigualdade ainda maior. Este seria o caso, por exemplo, de políticas redistributivas que possuem a renda como variável focal única e exclusiva (Sen, 1992). Por outro lado, a experiência dos programas de transferência de renda condicionada, que vêm sendo nos últimos anos implementados no Brasil e em outros países da América Latina, demonstra que meios liberais podem ser às vezes muito propícios a realizar fins nada liberais. Dewey pregava não haver oposição em defender meios democráticos liberais combinados com fins que são socialmente radicais. Se políticas liberais comprovadamente promovem a redução da desigualdade social, por que não apoiá-las? A abordagem prática da democracia suporta uma postura instrumentalista que se vale de variados meios para promover os fins da justiça social. Em termos concretos, uma abordagem analítica pragmática pode explicar de forma consistente e coerente a opção por políticas públicas que tomem como meios programas de transferência condicionada de renda pautados por princípios liberais uma vez que os mesmos realizam hoje de forma inegável os fins da justiça distributiva endossados pelos socialistas desde o século XIX.

Uma democracia pragmática transforma fins em meios, e não meios em fins. Uma abordagem pragmática da democracia permite que se lide com fatos de forma menos preconceituosa, que se lide com valores de forma menos ideológica, que se lide, enfim, com a política de forma menos hipócrita. Ao prover, por exemplo, uma justificação consistente e coerente para a adoção de políticas públicas liberais que possuem como consequências incontestes a redução da desigualdade social, a democracia pragmática indica como determinadas premissas e postulados normativos podem e devem ser relativizados a fim de se atingirem fins que são empiricamente factíveis e desejáveis.

Um raciocínio prático como o aplicado acima à igualdade social pode ser estendido ao papel da igualdade política na democracia contemporânea, indo além da abordagem pragmática da relação entre meios e fins. Debates recentes sobre representação política indicam como o sentido da mesma deve ser alargado a fim de contemplar grupos sociais minoritários ou, em particular, grupos que se definem a partir do compartilhamento de identidades culturais que são tomadas como minoritárias devido à sua não inclusão paritária no processo político-decisório. Com origem nas discussões travadas na teoria política contemporânea acerca do multiculturalismo, especificamente nas demandas 
pela inclusão e representação de grupos sociais oprimidos (Young, 1989; 2000), e em conexão com os debates realizados no campo da teoria da justiça entre liberais e comunitaristas, ganha força, nos últimos anos, o conceito de "representação justa" (fair representation).

Trata-se, a representação justa, de conceito central na agenda da chamada "política da presença" (politics of presence), que possui entre seus principais expoentes Phillips (1998) e Williams (2000) e entre suas principais reivindicações o argumento de que a representação justa de grupos marginalizados depende de sua presença dentro dos órgãos legislativos. Em outras palavras, sustenta-se que os cidadãos pertencentes a grupos historicamente excluídos não são representados justamente se não contarem no parlamento com representantes que façam parte destes grupos. Fazer parte destes grupos, por sua vez, implica compartilhamento de identidade (por meio, por exemplo, de uma memória e de uma experiência comum) e não em identidade de interesses. De modo que se supõe, assim, que um representante branco não possa representar justamente os cidadãos negros, ou que um parlamentar homem não possa representar de forma justa os interesses das mulheres. Desta convicção resulta a defesa de mecanismos institucionais que garantam a presença que tornaria justa a representação. A política da presença, portanto, a fim de colocar em prática uma representação justa, requer uma revisão da ideia de igualdade política e de seu papel na democracia representativa.

Apesar dos evidentes aspectos normativos envolvidos nas demandas por representação justa, bem como do inegável papel da deliberação na defesa de uma política da presença, é certo que a mesma suscita contribuições não desprezíveis a uma abordagem pragmática da democracia que se propõe a alargar o conceito de representação política. Basta que se analisem de forma prática as ideias defendidas pela política da presença e, em particular, que se conceba instrumentalmente o papel da igualdade política na definição da democracia representativa. A fim de ser realizado, o ideal de representação justa (que se expressa em demandas bastantes concretas manifestadas na prática recente de diversos movimentos sociais) claramente impõe a revisão da igualdade política formal (o princípio "um homem, um voto"), da regra da maioria e do princípio da proporcionalidade.

Mais do que propugnar pelo estabelecimento de cotas em parlamentos, a política da presença coloca em evidência a necessidade de se re- 
formar o sistema eleitoral e o sistema partidário. No que toca ao sistema eleitoral, por exemplo, extensas discussões são travadas acerca da justa divisão dos distritos eleitorais nos Estados Unidos. A divisão distrital com base em raça (race-conscious districting), tão amplamente questionada pelas cortes norte-americanas, consiste em uma forma de fazer com que os "distritos maioria-minoria" (majority-minority districts) - isto é, os distritos cuja maioria dos residentes faz parte de uma minoria étnica - alavanquem a presença de representantes negros nos órgãos legislativos daquele país a partir da década de 1990.

Este exemplo permite ilustrar como uma teoria pragmática da democracia, ao defender o praticalismo como uma ferramenta valiosa de análise, pode se beneficiar desse tipo de demandas concretas colocadas pela política da presença a fim de levar a cabo a proposta de ampliação do conceito de representação política. Uma vez concebida de modo instrumental diante da complexidade não apenas social porém também cultural do mundo contemporâneo, a noção de igualdade política, desde sempre erigida em fundamento da democracia representativa e desde sempre alçada ao lugar de pressuposto lógico do sufrágio universal e das eleições, pode assumir novos significados a fim de tornar a representação mais democrática e a democracia mais representativa.

Pragmaticamente, uma questão a ser lançada diz respeito à compreensão do que significa proporcionalidade em um sistema eleitoral proporcional, bem como do que significa maioria em um sistema eleitoral majoritário. Concebida instrumentalmente, a ideia de igualdade política pode ensejar, por exemplo, redefinições de cálculo de quocientes eleitorais e redefinições distritais que privilegiem o caráter majoritário das minorias. Certamente, a fim de contemplar as demandas da política da presença advogadas de forma cada vez mais contundente por movimentos da sociedade civil organizada, é necessário mais do que modificar as instituições representativas através da criação de procedimentos e regras inclusivos, ou fazer com que os procedimentos e regras existentes se adaptem a uma proporção ditada pelas divisões étnicas, sexuais e raciais da sociedade. É necessário prover novo significado e novo alcance à representação política e às instituições representativas. E isso pode ser feito por intermédio dos mecanismos participativos e deliberativos que, não por coincidência, apresentam-se como espaço privilegiado para a expressão dos interesses dos grupos sociais e culturais minoritários. 
Outra questão que pode ser apresentada de um ponto de vista prático a partir das demandas feitas em defesa da representação justa de grupos historicamente marginalizados diz respeito ao significado das minorias, seu papel político e o lugar apropriado para a representação institucional de seus interesses. Os debates sobre multiculturalismo, política da diferença e política da presença jogam luz sobre a inclusão política de minorias culturais. Porém, como fazer para separar, em termos concretos, minorias culturais de minorias políticas? Ora, ao passo que é razoável assumir que toda minoria cultural seja uma minoria política, não é nada racional supor que toda minoria política seja também uma minoria cultural. Cabe, portanto, perguntar: por que mecanismos institucionais de inclusão das minorias culturais deveriam ter prioridade diante de mecanismos de conversão de minorias partidárias em maiorias políticas? Talvez urgisse aqui conferir uma abordagem mais instrumental à representação de grupos culturais, concebendo-os como minoritários apenas na medida em que seus interesses possam se traduzir, politicamente, em uma representação partidária minoritária.

No Brasil, as conferências nacionais de políticas públicas são claramente espaços nos quais os grupos sociais e culturais minoritários convertem-se em maiorias políticas eventuais. Enquanto experiências participativas e deliberativas que são, as conferências nacionais mostram que é possível não apenas dar voz às demandas dos grupos minoritários como também torná-las presentes no Parlamento. Mesmo que esses grupos não consigam eleger seus candidatos, podem se valer das conferências nacionais para fazer seus interesses serem representados no Poder Legislativo. A força legitimadora de um projeto de lei que encontre forte respaldo nas conferências nacionais pode operar como uma espécie de "representação retrospectiva", para usar o conceito de Mansbridge (2003) - ou seja, os parlamentares podem ter fortes incentivos (eventualmente, aliás, transcendendo a própria base programática de seu partido ou as prioridades de suas bases eleitorais tradicionais) para encampar demandas apresentadas nas conferências nacionais e assim conquistar possíveis novos grupos de eleitores, ou retomar seus laços com outros antigos. As conferências nacionais facultariam, assim, a representação de minorias políticas que muitas vezes não logram converter-se em maiorias partidárias.

As conferências nacionais de políticas públicas servem, portanto, como uma forma de mediação política que corre paralela às eleições e aos partidos, mas que, como eles, converge na realização da democracia 
através das instituições representativas. A participação da sociedade civil e as deliberações por ela operadas em conjunto com o governo nas conferências nacionais resultam em instituições mais representativas (pelo grau de abrangência e inclusividade dos interesses que passam a apreciar com maior ênfase) e em uma representação política fortalecida pelos novos incentivos recebidos pelos parlamentares para iniciar o processo legislativo em determinadas direções.

Práticas democráticas participativas como as conferências nacionais facultam que interesses políticos minoritários sejam representados no Poder Legislativo mesmo quando não se encontrem encampados nas plataformas partidárias. As diretrizes de políticas públicas contidas nas resoluções finais das conferências nacionais propulsionam a atividade legislativa do Congresso Nacional oferecendo aos parlamentares um amplo cardápio de demandas formatadas diretamente de acordo com as preferências da sociedade civil em um ambiente não eleitoral e, portanto, livre de influências partidárias, do apelo midiático e de qualquer outra eventual interferência na formação da opinião e da vontade dos cidadãos. A forte presunção de legitimidade popular de que dispõem as proposições derivadas das conferências nacionais faculta que as mesmas se superponham à lógica tradicional de distribuição dos interesses partidários, fazendo, por exemplo, com que um partido majoritário eventualmente decida representar um interesse previamente não representado - seja por não ter sido encampado por nenhum partido, seja por ter sido previamente encampado por um partido minoritário. Ter-se-ia, assim, através da participação e da deliberação, mais uma forma para a democracia se expressar como representação.

Quanto àqueles grupos que não logram ser representados senão como minorias políticas, podemos nos perguntar se o lugar de sua representação também não poderia ser, de acordo com a versão madisoniana da democracia (Dahl, 1956), as instituições contramajoritárias - vale dizer, os órgãos judiciais não eleitos. A exigência prática de uma representação justa, tal como advogada por muitos movimentos sociais hoje, pode alimentar uma análise pragmática da democracia no sentido de fomentar uma compreensão ampliada da representação política que conceba as chamadas instituições contramajoritárias como sendo, antes, pró-minoritárias. Ou seja, o caráter não majoritário dos órgãos jurisdicionais pode se revelar propício para produzir uma representação propriamente política (e não meramente judicial) de minorias sociais e culturais que não logrem converter-se em maiorias políticas 
(nem mesmo por recurso às práticas participativas e deliberativas que alavancam a sua representação parlamentar).

Nesse sentido, os grupos historicamente marginalizados, a despeito de buscarem a representação de seus interesses nos órgãos legislativos e na administração pública, deveriam buscá-la também nos órgãos judiciais - em particular nas cortes constitucionais que, em sua função de salvaguardar os direitos sociais e culturais constitucionalmente assegurados, podem atuar, no exercício de seu papel institucional contramajoritário, como uma instância pró-minoritária. Isso, de fato, vem se verificando no Brasil, na medida em que o Poder Judiciário tem avançado de forma expressiva no reconhecimento de uniões homoafetivas e nos direitos a ela correlatos, como aqueles relativos à adoção e à herança de casais formados por pessoas do mesmo sexo. Colocada de outro modo, a questão consiste em saber em que medida os fundamentos das demandas da 'política da presença' não legitimariam a ampliação da representação política para instituições não eletivas que, contudo, possam eventualmente não apenas dar voz a tais demandas, como também torná-las presentes.

\section{A Dimensão Crítica: Experimentalismo}

A dimensão crítica da teoria pragmática da democracia pauta-se pelo experimentalismo. Por experimentalismo entendo a adoção de uma postura experimental que implica, em alguma medida, converter fatos em normas, práticas em instituições, dogmas em riscos e princípios em fins. O experimentalismo clama pelo empoderamento político dos cidadãos ordinários por meio da institucionalização progressiva de práticas democráticas conduzidas na, pela e através da sociedade civil. $\mathrm{O}$ experimentalismo é a invenção do novo, a transformação do velho, a substituição da normatividade pela factualidade. Situando-se em algum lugar entre os ideais de revolução e reforma, o experimentalismo permite conjugar a política no futuro do pretérito, e fazer da democracia simultaneamente experiência e experimentação.

O experimentalismo permite que a crítica realize seu caráter prático, isto é, transformativo. A dimensão crítica da democracia pragmática repele o caráter meramente especulativo e contemplativo da teoria e, por outro lado, implica a adoção de uma postura ativa, interventiva, criativa e, assim, transformativa. Algumas das características do pragmatismo mencionadas anteriormente - tais como a futuridade, o falibi- 
lismo e a revisabilidade - explicam a disposição experimentalista da democracia pragmática, que, além do antifundacionalismo, também muito se nutre do contextualismo.

O contextualismo é possivelmente a característica do pragmatismo que mais encontra reflexos na história do pensamento, e é certamente aquela que mais o aproxima do marxismo. Duas ideias são centrais para que se compreenda o contextualismo: experiência e prática. As duas, na verdade, encontram-se intimamente relacionadas: para o pragmatismo, experiência é aquilo que envolve uma ação causada por pessoas e que produz consequências que podem ser compartilhadas por outras pessoas. A definição de uma experiência como democrática depende, assim, de que as consequências produzidas por uma dada ação política possam ser compartilhadas por pessoas outras além daquelas cuja prática as suscitou, de modo a beneficiar a todas conjuntamente.

A experiência é definida por Dewey como uma interação livre entre seres humanos singulares, a qual desenvolve e satisfaz a necessidade e $o$ desejo por meio de uma ampliação do conhecimento das coisas tais como elas são. Duas lições importantes decorrem daqui. A primeira refere-se à compreensão da tarefa da democracia como sendo a de criar uma experiência mais livre e mais humana, na qual todos compartilham e para a qual todos contribuem (Dewey, 1939). Tal compreensão permite conceber a democracia como um processo - e um processo aberto e infinito - que toma a experiência humana simultaneamente como um fim e como um meio para a sua realização. Este papel da experiência humana na definição da democracia responde pela confiança do pragmatismo no cidadão ordinário, ou melhor, na capacidade do homem comum de criar e recriar, por meio de sua ação cotidiana, uma cultura política cooperativa e favorável à realização de suas necessidades e desejos. O que ensejaria tal cooperação seria justamente o compartilhamento das consequências da ação social - o que envolve a todos e a cada um, tornando os indivíduos individual e coletivamente responsáveis pelos seus atos.

A segunda lição diz respeito à ampliação do conhecimento que se encontra na base do tipo de ação política pressuposta pela experiência humana que é constitutiva de uma democracia pragmática. Tal ação deve ser orientada por uma inteligência capaz de converter experiência ordinária em experimentalismo político - ou, em outras palavras, 
converter a prática cotidiana dos homens comuns em inovação política institucional. A noção de inteligência com a qual o pragmatismo busca ocupar o lugar da razão em sua teoria da ação parte da ideia de que a função da mente é a de sempre projetar fins novos e cada vez mais complexos, de modo a livrar a experiência da rotina e do capricho. É o uso da inteligência que deve orientar a ação, e isso não significa simplesmente valer-se do pensamento para realizar objetivos preestabelecidos. Dewey sustentava que a inteligência desenvolve-se no contexto da própria ação, de modo a propiciar realizar possibilidades que não são - e, às vezes, nem poderiam ser - previamente estabelecidas.

A "ação inteligente" é, assim, aquela que se abre a fins desconhecidos previamente pelos agentes. Isso permite alimentar o experimentalismo político da democracia, dando-lhe uma direção criativa e criadora. Uma ação inteligente - e não apenas racional - é instrumental na medida em que determina as características da experiência futura. Para o pragmatismo, a preocupação primária da inteligência deve ser o futuro, aquilo que ainda não foi realizado e que, por isso, ainda pode ser controlado. A inteligência deve, portanto, conduzir a ação na direção de um futuro que corresponda à projeção daquilo que é desejável no presente, assim como deve inventar os meios para a sua realização. É substituindo a definição apriorística de fins determinados e determináveis pela invenção inusitada e espontânea de meios capazes de produzir consequências desejáveis e viáveis que a inteligência pragmática manifesta-se em uma prática democrática aberta ao experimentalismo político.

Assim definido pelas ideias de prática e de experiência, o contextualismo que marca uma abordagem experimental da democracia joga luz nas condições e circunstâncias que podem ser alteradas por meio de uma ação humana inteligente - e que, uma vez o sejam, podem criar um estado de coisas mais desejável. Dito de outro modo, o contextualismo joga luz sobre os fatos e, ao fazê-lo, indica o protagonismo que os mesmos devem assumir na criação do novo e na escolha dos vários futuros possíveis que são dados pela materialidade do presente. Os fatos devem impulsionar toda ação que se quer inteligente, isto é, que tem por propósito intervir criativamente no futuro por meio de uma transformação das condições do presente. A adoção de uma atitude experimentalista implica observar de forma crítica os fatos que constituem cada contexto, conferindo-lhes força normativa e tomando-lhes como fonte de legitimação para a ação política. 
Tomar os fatos como propulsores da ação política significa, em outras palavras, tomar as demandas sociais presentes em cada contexto como determinantes das escolhas e decisões institucionais. Este ponto é importante para que se compreenda como o consequencialismo pragmatista afasta-se do utilitarismo e de qualquer outra abordagem maximizadora que defenda um processo de tomada de decisão orientado pelas consequências das mesmas. O teste pragmatista das consequências não é desprovido de critérios substantivos, assim como não se reduz a um mero procedimento maximizador; ao contrário, qualquer escolha ou decisão institucional que dele resulte buscará sempre promover um teste da viabilidade empírica das consequências que depende justamente de um ajuste entre as mesmas e as demandas sociais que podem ser deduzidas do contexto no qual as escolhas e decisões são tomadas e produzirão seus efeitos. É por isso que o pragmatismo, com sua visão experimentalista da política, requer que os fatos ocupem lugar central na definição do contexto dentro do qual uma decisão em cada situação institucional há de ser tomada. Os fatos - mais dinâmicos que as normas e menos voláteis que os interesses e opiniões - são os mais genuínos portadores das demandas socais.

Se são os fatos portadores das demandas sociais, devem ser eles também condutores de inovações político-institucionais. Uma abordagem pragmática da democracia, a fim de fazer valer sua dimensão crítica, requer que os fatos sejam ouvidos e, mais do que isso, que sejam levados a sério. Esta não é uma afirmação trivial. Não o é, sobretudo quando, conforme argumentado anteriormente, pode-se observar sem dificuldades que a democracia representativa vem reproduzindo a si mesma ao longo dos séculos por meio da reprodução de alguns de seus princípios, instituições e procedimentos. $\mathrm{E}$, mais do que isso, que esta reprodução encontra-se associada a outra, qual seja, a reprodução do conteúdo semântico do próprio conceito de representação política. Tal situação indica, por um lado, a capacidade da democracia representativa de perseverar-se em sua essência, mas, por outro, denuncia também a sua limitada habilidade de adaptar-se aos fatos - ou, talvez, de aceitar que os mesmos possam questionar e intervir naqueles princípios, instituições e procedimentos que historicamente a definem.

Um fato que não pode mais deixar de ser ouvido, posto que o mesmo fala cada vez mais alto, é o crescimento do papel institucional das cortes constitucionais e seu impacto político nas democracias contemporâneas. Este não é um fato novo, porém é um fato que vem ganhando 
cada vez mais força e tornando-se paulatinamente mais explícito em lugares onde não o era antes. No Brasil, em particular, este é um fato relativamente recente, que vem assumindo uma proeminência veloz e, ao que tudo indica, inexorável. Do ponto de vista de uma teoria democrática liberal, zelosa do princípio da separação de poderes e do sistema de freios e contrapesos, pode-se dizer, de um modo geral, que há pelo menos duas atitudes diante de tal fato: rechaçá-lo ou aceitá-lo.

Rechaçar o crescimento institucional das cortes constitucionais e seu papel político, contudo, implica acatar a situação exatamente como ela se apresenta faticamente. Por outro lado, aceitar tal fato possibilita uma atitude menos passiva, pois, uma vez que se assuma a sua irreversibilidade e se o tome como um movimento espontâneo da democracia, pode-se partir de uma compreensão da situação para uma intervenção sobre a mesma. Em outras palavras, pode-se tomar tal fato não como uma ameaça à representação política, às instituições representativas ou à democracia; mas, ao contrário, como um sinal de que a primeira precisa ser ressignificada, as segundas, reconfiguradas e a terceira, fortalecida. Se não é possível controlar os fatos, deve ser possível, ao menos, domesticá-los.

A abordagem pragmática da democracia encara o fato do crescimento do papel político das cortes constitucionais como uma oportunidade de exercer sua vocação experimentalista. Assim, o concebe não como uma usurpação de funções das instituições representativas, mas como uma ampliação daquilo que se considera uma função representativa. Isto possibilita que se amplie o escopo da representação política e o espaço de sua aplicação, criando-se soluções institucionais que possibilitem fazer das cortes constitucionais instâncias efetivamente representativas, a despeito da inaplicabilidade do dispositivo eleitoral enquanto mecanismo de legitimação e accountability.

Tendo isso em vista, um primeiro aspecto a ser abordado é o significado da função representativa. A questão a ser respondida é: o que torna uma instituição ou um ator político representativo? O pragmatismo, surgido originalmente como uma teoria da significação, sustenta que o significado de um conceito é dado pela experiência, de modo que o mesmo encontra-se em permanente mutação de acordo com os fatos que se sucedem e da compreensão que deles se possui. Desse modo, a fim de saber o que um conceito significa no momento presente é necessário antecipar suas consequências. Um conceito é, em ato, o que ele é 
no seu futuro, ou seja, seu significado apenas pode ser conhecido através de suas consequências práticas. Em outras palavras, os pressupostos e fundamentos de um determinado objeto importam menos do que os efeitos que ele acarreta na prática. Esses efeitos são medidos através de consequências observáveis naqueles que são afetados - ou potencialmente afetados - pelo objeto em questão. O significado de um conceito é, assim, conferido pelas consequências de sua aplicação empírica. A prática de um conceito, afinal, pode desmentir a teoria que se erigiu em seu nome e falsificar a verdade de suas premissas.

No caso da representação política, portanto, o que deve permitir considerar uma instituição ou ator político como representativo é justamente o caráter representativo das consequências engendradas por uma determinada atividade política. Se as consequências da atividade de uma determinada instituição ou de certo agente logram ser representativas das demandas existentes na sociedade, então tal instituição e agente são representativos. É o compartilhamento das consequências políticas de uma determinada atividade (seja esta a promulgação de uma lei, a execução de uma política pública, seja a tomada de uma decisão judicial) e sua correspondência a demandas presentes na sociedade o que a torna representativa.

Os efeitos erga omnes das decisões das cortes constitucionais no exercício do controle de constitucionalidade tornam inevitável o compartilhamento das consequências de tal atividade judicial. Uma vez que as cortes apenas agem quando provocadas e uma vez que aqueles competentes a fazê-lo no caso do controle concentrado de constitucionalidade são agentes eleitos ou entes representativos da sociedade civil, é razoável supor que a mudança de status quo propiciada pela contestação de uma lei corresponde a demandas presentes na sociedade, mesmo que de forma não necessariamente majoritária. De outro modo, atores da sociedade civil organizada - em particular os próprios partidos políticos - não levariam às cortes as demandas que consideram não satisfeitas pelo processo legislativo ordinário. Ou as decisões judiciais não seriam estatisticamente mais respeitadas do que as leis obedecidas, quando a sanção pelo descumprimento de ambas é potencialmente a mesma. O simples caráter de legislador negativo das cortes constitucionais já responde pelo seu papel político, assim como o mero compartilhamento das consequências de suas decisões responde pelo seu caráter potencialmente representativo. 
Às afirmações acima se pode facilmente opor o argumento de que as decisões resultantes da atividade jurisdicional podem, de acordo com o exposto, ser consideradas socialmente representativas, porém não politicamente válidas ou legítimas. É por isso que, conforme argumentei em um momento anterior deste texto, a ressignificação da representação política depende da reconsideração de suas condições de validade e legitimidade. Em outras palavras, o objetivo de considerar as cortes constitucionais instâncias de representação política só pode ser alcançado se lhe forem providos: 1) meios consistentes de delegação política provenientes diretamente da constituição e dos outros poderes do Estado, e indiretamente dos eleitores; 2) mecanismos de revocabilidade que tornem controláveis tanto os principais como os agentes desta relação de delegação, e 3) uma forma de legitimação que suplemente a ausência de eleição direta e valide a escolha indireta propiciada pelos meios de delegação.

É inquestionável, pelo menos desde Mill, que eleições induzem e produzem representação. Isso não impede, contudo, que se questione se as eleições de fato produzem democracia (Przeworski, Stokes e Manin, 1999) ou se a regra da maioria é de fato democrática (Dahl, 1956), de modo que resta em aberto a questão de saber se as eleições apenas engendram representação ou se engendram uma representação democrática (Urbinati, 2006).

Tal questionamento não implica, todavia, endossar as críticas apresentadas por parte da teoria da escolha social à democracia, ao aplicar o Teorema da Impossibilidade de Arrow (1963) à política a fim de sustentar que a agregação social de preferências individuais levaria a resultados incoerentes e inconsistentes - seja porque estas podem ser reveladas de forma estratégica, seja porque as regras de escolha podem ser manipuladas por meio de um controle da agenda que determine a ordenação das preferências ou das decisões a serem tomadas com base nelas etc. -, de modo que sistemas de votação com mais de duas alternativas (como funcionam tanto as eleições populares para escolher os representantes que exercerão mandatos nas instituições políticas como as votações internas dessas instituições quando esses mesmos representantes fazem escolhas em nome de seus eleitores) seriam injustos e inadequados e fariam com que a democracia fosse irracional, arbitrária e desprovida de sentido (Riker, 1982). De todo modo, essa crítica inevitavelmente reforça o questionamento enunciado acima e confere algum tipo de validade às seguintes suposições: 1) a chamada crise da 
democracia representativa é, na verdade, uma crise anunciada do método moderno de produção de representação, as eleições; 2) representação e democracia requerem um liame mais amplo do que as eleições podem oferecer, ou, em outras palavras, a fim de ser democrática a representação política deve ser produzida por mecanismos outros que não apenas o eleitoral.

Quanto à questão específica de estender a representação política às cortes constitucionais, poder-se-ia ainda acrescentar uma terceira suposição, validada por constatações como a de Przeworski, Stokes e Manin (1999) no sentido de que, se é certo que eleições engendrem representação, é contudo duvidoso que as mesmas engendrem accountability suficiente para que a representação política possa ser efetivamente chamada de democrática: 3) a falibilidade dos sistemas eleitorais e a dificuldade dos mecanismos de votação em tornar democráticos os seus resultados e as decisões das instituições políticas majoritárias (levando-se em conta aqui não apenas a falibilidade dos sistemas eleitorais majoritários, mas também os paradoxos e déficits representativos gerados pelos sistemas proporcionais de lista aberta, por exemplo) são condições de legitimação (necessárias, porém jamais suficientes) das decisões políticas e do caráter representativo de instituições não majoritárias como as cortes constitucionais - na medida em que (e apenas se) estas possam atuar simultaneamente como principal e agente em relações de delegação de poder político e possam ser controladas e legitimadas por mecanismos não exclusivamente eleitorais.

Não é a toa que críticas à democracia como a mencionada acima de Przeworski et alli (1999) no sentido de que o accountability eleitoral não seria suficiente para induzir a representação quando os eleitores possuem informação incompleta, bem como a crítica mais geral de que os eleitores não possuem informação suficiente (ou, em outras palavras, são ignorantes em demasia) para fazerem escolhas racionais e razoáveis, vêm sendo rebatidas recentemente justamente por meio da teoria da delegação (Lupia e McCubbins, 1998); teoria esta - ressalte-se - que, entre outras coisas, fundamenta-se em postulados cognitivos que conferem centralidade à antecipação de consequências da ação - seja daqueles que escolhem, seja daqueles que são escolhidos. A teoria da delegação vem, assim, reforçar a democracia representativa, seja possibilitando que esta se defenda das acusações de déficit democrático da representação em instituições majoritárias, seja facultando que a representação política seja fortalecida ao ampliar-se e atingir instituições 
não majoritárias. É com este último propósito, aliás, que a teoria da delegação vem sendo apropriada por formulações de uma ideia de governança aplicável às novas democracias do pós-guerra marcadas por intensos processos de judicialização da política (Stone Sweet, 2000; Stone Sweet e Thatcher, 2003).

Tendo tudo isso em vista a democracia pragmática defende que a representação política não deve encontrar limites nos mecanismos eleitorais, tampouco na aplicação estrita da regra da maioria. Em outras palavras, a democracia pragmática vindica abertura para experimentar modos de aferição de accountability da representação diferentes da eleição, critérios de avaliação da democracia diferentes da regra da maioria, e mecanismos de legitimação que transcendam a ambos ao deslocar-se para um plano ex post (baseados nas consequências da decisão) e não ex ante (fundado nas escolhas do decisor).

Uma análise pragmática da democracia possibilita, por exemplo, não apenas que a representação política seja estendida para atores não eleitos que, contudo, seriam eventualmente investidos de legitimidade democrática para agir em nome do interesse público; mas permite também que sejam considerados como uma extensão da representação política formal os espaços informais nos quais ela se exerce, em um primeiro momento, através da atividade daqueles atores. Nesse contexto podem se inserir análises tão diversas como as que defendem a expansão da representação política para a sociedade civil com base na pluralização dos atores e na diversificação do locus de seu exercício (Gurza Lavalle et alli, 2006a; 2006b) ou com base nos vínculos de afinidade criados por práticas participativas mediante a mobilização de certos temas (Avritzer, 2007), e as que defendem, como neste artigo, que 1) a representação política exercida nas instituições do Estado se fortaleça através de experiências democráticas participativas e deliberativas que permeiam a sociedade civil; e 2) as instituições políticas estatais se fortaleçam mediante um arranjo delegativo de representação que faculte, no final das contas, uma nova configuração a um dos principais sustentáculos liberais da democracia moderna: o princípio da separação de poderes.

O experimentalismo político fortalece a democracia representativa possibilitando uma resposta dialética às tentativas de superá-la. A representação política só pode ser superada se forem preservadas as instituições que lhe servem de suporte; por outro lado, a representação 
política só pode ser preservada se forem superadas a lógica constitutiva e a dinâmica interna dessas mesmas instituições. O oposto da representação não é a participação ou a deliberação. O oposto da representação é a não representação. Daí que qualquer tentativa de superação dos paradoxos da democracia representativa apenas pode ser engendrada no útero da própria democracia representativa. Mas, para que o parto seja bem-sucedido e o rebento vigoroso, talvez seja necessária a experimentação de alguns mecanismos não tradicionais de fertilização da representação política.

\section{EM TORNO DE UM NORMATIVISMO MATERIALISTA}

Em suas dimensões epistemológica, analítica e crítica, a democracia pragmática implica uma abordagem reflexiva, prática e experimental da política. Tal abordagem revela o escopo e o alcance da teoria da democracia pragmática, bem como a medida na qual ela inspira-se no pragmatismo a fim de clamar por uma compreensão normativa da democracia representativa que, contudo, revele-se aberta a uma orientação empírica. É esta abertura para a empiria que permite à própria teoria submeter-se ao teste pragmatista: sua viabilidade depende das consequências que seus postulados normativos produzam nas instituições políticas.

O consequencialismo pragmatista é, assim, ele mesmo uma estratégia metodológica para aproximar teoria política normativa e ciência política empírica, isto é, para superar o divórcio entre normatividade e empiria que hoje caracteriza a ciência política, e em particular caracteriza os estudos contemporâneos sobre a democracia. A democracia pragmática busca conciliar os valores e ideais que desde sempre alimentaram os pressupostos normativos da democracia com a viabilidade institucional e política que falta às concepções contemporâneas erigidas em crítica à democracia representativa. Nisso reside o seu caráter pragmático, mas não apenas nisso.

Conforme argumentado ao longo deste artigo, são muitas as características do pragmatismo apropriadas pela teoria da democracia pragmática. Esta busca atingir um equilíbrio entre os valores e ideais normativos e as instituições e arranjos políticos práticos. Ou seja, almeja, como outras concepções recentes que também se nutrem do pragmatismo (Fung, 2007; Unger, 2007), seguir uma orientação pragmática em torno das evidências empíricas sem, no entanto, abrir mão dos valores 
e ideais que constituem a tradição democrática. Uma de suas diferenças, contudo, é que deseja fazê-lo sem renunciar ao caráter representativo da democracia e sem deixar de considerá-la em seu falibilismo - o que implica aceitar que um arranjo político que espelhe um valor ou reflita uma crença em um determinado momento possa ser falsificado em um momento seguinte, na medida em que valores e crenças são mutáveis e revisáveis e os "hábitos da mente" que levam os homens à ação política são dinâmicos e não estáticos.

A democracia pragmática permite, portanto, que se endossem valores sem abrir mão dos fatos. Ao rejeitar-se a dicotomia entre fatos e valores, busca-se fazer da normatividade algo mais que um preceito regulador de uma realidade não apenas impossível, mas muitas vezes também indesejável ou incompatível com os valores e ideais por ela mesma pressupostos. Propõe-se, assim, a uma concepção de democracia mais imune às normas que engessam a realidade e mais permeável à materialidade dos fatos que constituem o dinamismo social.

Ao aproximar o pragmatismo do materialismo, a democracia pragmática possibilita que o mundo dos fatos adentre a normatização sobre a política, levando, contudo, a um materialismo cuja lógica explica-se não apenas na história, mas na dialética de um futuro possível que reside na antecipação das consequências do presente. Ao transpor os limites da história sem dela abrir mão, o normativismo pode valer-se de uma dialética dos fatos presentes para projetar-se no futuro sem acorrentar-se à ilusão de ideais reguladores e máximas universais. Tem-se, assim, um normativismo materialista (Pogrebinschi, 2009), uma proposta epistemológica para uma reflexão dialética sobre as coisas políticas que encontra no futuro do pretérito o tempo de conjugação de suas premissas teóricas e postulados práticos.

Enquanto expressão do normativismo materialista, o conceito de democracia pragmática apresenta-se como normativo não no sentido de regulação do presente ou do apelo a uma regra universal que oriente a sua aplicabilidade, mas no sentido de um conceito orientado a um dever ser do próprio conceito, mais do que por sua história. Poder-se-ia dizer que o conceito de democracia pragmática consiste, assim, em um "conceito de movimento" (Koselleck, 1985), isto é, um conceito que possui um horizonte de expectativas maior do que o seu espaço de experiência. Nesse sentido, o conceito de democracia pragmática desprende-se da história para buscar sua materialidade no futuro. Suas 
experiências cedem lugar às expectativas, as quais não se formam a partir de um olhar que se dirige para trás, mas fitando o que está por vir pela frente. $O$ único filtro que se impõe a esse olhar, contudo, são as lentes que o conduzem a seu contexto específico, a realidade empírica das instituições políticas. Mas a democracia pragmática, conceito de movimento que é, em sua busca por um sempre novo horizonte de expectativas, faz desse foco um espelho refletor de múltiplas e variadas possibilidades interpretativas.

Nesse exercício interpretativo que serve de campo de formação ao conceito, entende-se o significado de uma concepção materialista da normatividade, ou seja, daquilo que chamo de normativismo materialista. Trata-se de uma fusão do dever ser com o ser, das expectativas futuras com as condições presentes, da projeção no real de um devir em constante formação e atualização de si mesmo. Trata-se de superar o divórcio entre teoria e prática por meio de uma práxis interna à própria teoria. Trata-se de postular a teoria como prática, uma prática de fazer teoria que consiste precisamente em romper com a práxis teórica. É nesse sentido que a democracia pragmática clama por uma superação dialética do conceito de democracia representativa. O normativismo por ela pressuposto não se baseia em uma crença de que as condições materiais hoje existentes no mundo conduzirão na prática ao fim da representação política e ao restabelecimento de uma forma direta de democracia, como parecem crer alguns dos apóstolos das concepções participativas e deliberativas de democracia.

A fim de realizar o caráter dialético da democracia pragmática, a representação política deve gestar e fortalecer em si mesma os arranjos participativos e deliberativos que possibilitem a sua superação. Isso significa tomar a própria representação como participação e deliberação - o que implica, certamente, não apenas uma reconfiguração conceitual, no plano teórico, mas também, e sobretudo, um redesenho institucional, no plano empírico. O desafio que se encontra em aberto é o de tornar as experiências participativas e deliberativas constitutivas das instituições representativas.

Os supostos paradoxos da democracia representativa apenas podem ser resolvidos através de sua própria afirmação, isto é, por meio do seu fortalecimento. É por esta razão, entre outras, que a teoria democrática contemporânea não pode se furtar de reinvestigar a representação política, indicando caminhos que sejam factualmente realizáveis e, so- 
bretudo, que não estejam cegos pela sedução de um normativismo deontológico. Isso, por sua vez, requer que se desfaça a tensão entre empiria e normatividade de modo a conseguir, finalmente, conciliar a necessidade empírica de explicar as instituições políticas com a ambição normativa de propor formas de organização política mais desejáveis.

(Recebido para publicação em novembro de 2008)

(Reapresentado em julho de 2010)

(Versão definitiva em setembro de 2010) 


\section{REFERÊNCIAS BIBLIOGRÁFICAS}

AMORIM NETO, Octavio e SANTOS, Fabiano. (2005), “La Ciencia Política en el Brasil: El Desafío de la Expansión". Revista de Ciencia Política, vol. 25, no 1, pp. 101-110.

ARROW, Kenneth J. (1963), Social Choice and Individual Values. New York, Wiley Press.

AVRITZER, Leonardo. (2009), Participatory Institutions in Democratic Brazil. Baltimore/Washington, Johns Hopkins University Press/Woodrow Wilson Center.

. (2007), "Sociedade Civil, Instituições Participativas e Representação: Da Autorização à Legitimidade da Ação". DADOS, vol. 50, no 3, pp. 443-464.

. (2002), Democracy and the Public Space in Latin America. Princeton, Princeton University Press.

BARBER, Benjamin. (1984), Strong Democracy. Participatory Politics for a New Age. Berkeley, University of California Press.

BOHMAN, James. (1996), Public Deliberation. Pluralism, Complexity, and Democracy. Cambridge, MIT Press.

CASTIGLIONE, Dario e WARREN, Mark. (2006), Rethinking Democratic Representation: Eight Theoretical Issues. Centre for the Study of Democratic Institutions, University of British Columbia. Manuscrito.

COHEN, Joshua. (1989), “Deliberation and Democratic Legitimacy”, in A. Hamlin e P. Petit (eds.), The Good Polity: Normative Analysis of the State. New York, Blackwell. (Publicado também em (1997), BOHMAN, James e REHG, William (eds.), Deliberative Democracy. Essays on Reason and Politics. Cambridge, MIT Press.)

DAHL, Robert. (1956), A Preface to Democratic Theory. Berkeley, University of California Press.

(1997). "Procedural Democracy", in R. E. Goodin e P. Pettit (eds.), Contemporary Political Philosophy. An Anthology. Oxford, Blackwell.

DEWEY, John. (1998) [1937]. “Democracy is Radical”. The Essential Dewey. Volume I: Pragmatism, Education, Democracy. Bloomington, Indiana University Press.

. (1998) [1939]. "Creative Democracy - The Task Before Us". The Essential Dewey. Volume I: Pragmatism, Education, Democracy. Bloomington, Indiana University Press.

DRYZEK, John S. (2000), Deliberative Democracy and Beyond. Oxford, Oxford University Press.

EPSTEIN, David e O'HALLORAN, Sharyn. (1999), Delegating Powers. Cambridge, Cambridge University Press.

FISHKIN, James. (1995), The Voice of the People: Public Opinion and Democracy. New Haven, Yale University Press.

. (1991), Democracy and Deliberation: New Directions for Democratic Reform. New Haven, Yale University Press.

FUNG, Archon. (2007), “Democratic Theory and Political Science: A Pragmatic Method of Constructive Engagement". American Political Science Review, vol. 101, no 3, pp. 443-458. 


\section{Democracia Pragmática: Pressupostos de uma Teoria Normativa...}

. (2004), Empowered Participation. Reinventing Urban Democracy. Princeton, Princeton University Press.

e WRIGHT, Erik Olin. (2003), Deepening Democracy: Institutional Innovations in Empowered Participatory Governance. London, Verso.

GURZA LAVALLE, Adrian et alli. (2006a), “Representação Política e Organizações Civis: Novas Instâncias de Mediação e os Desafios da Legitimidade". Revista Brasileira de Ciências Sociais, vol. 21, no 60, pp. 43-66.

(2006b), "Democracia, Pluralização da Representação e Sociedade Civil". Lua Nova, no 67, pp. 49-103.

GUTMANN, Amy. (1996), Democracy and Disagreement. Cambridge, Harvard University Press.

e THOMPSON, Dennis. (2004), Why Deliberative Democracy? Princeton, Princeton University Press.

HABERMAS, Jürgen. (1995), Between Facts and Norms. Contributions for a Discourse Theory of Law and Democracy. Cambridge, MIT Press.

KIEWIET, D. Roderick e McCUBBINS, Mathew. (1991), The Logic of Delegation. Chicago, University of Chicago Press.

KOSELLECK, Reinhart. (1985), Futures Past: On the Semantics of Historical Time. Cambridge/London, The MIT Press.

LUPIA, Arthur e McCUBBINS, Mathew D. (1998), The Democratic Dilemma. Cambridge, Cambridge University Press.

LUPIA, Arthur, McCUBBINS, Mathew e POPKIN, Samuel. (2000), Elements of Reason. Cambridge, Cambridge University Press.

MACKIE, Gerry. (2003), Democracy Defended. Cambridge, Cambridge University Press.

MANIN, Bernard. (1996), Principes du Gouvernement Représentatif. Paris, Calmann-Levy.

MANSBRIDGE, Jane. (2003), “Rethinking Representation”. American Political Science Review, vol. 97, no 4, pp. 515-528.

. (1980), Beyond Adversary Democracy. Chicago, University of Chicago Press.

PATEMAN, Carole. (1970), Participation and Democratic Theory. Cambridge, Cambridge University Press.

PEIRCE, Charles. (1998) [1905], “How to Make Our Ideas Clear”. The Essential Peirce, Volume II (1893-1913). Bloomington, Indiana University Press.

PHILLIPS, Anne. (1998), The Politics of Presence. Oxford, Oxford University Press.

PITKIN, Hanna. (1967), The Concept of Representation. San Francisco, University of California Press.

POGREBINSCHI, Thamy. (2009), O Enigma do Político. Marx contra a Política Moderna. Rio de Janeiro, Civilização Brasileira.

PRZEWORSKI, Adam, STOKES, Susan e MANIN, Bernard (eds.). (1999), Democracy, Accountability, and Representation. Cambridge, Cambridge University Press.

RAWLS, John. (1993), Political Liberalism. New York, Columbia University Press. 


\section{Thamy Pogrebinschi}

RIKER, William H. (1982), Liberalism against Populism. A Confrontation between the Theory of Democracy and the Theory of Social Choice. Prospect Heights, Waveland Press.

ROSANVALlON, Pierre. (2006), La Contre-Démocratie. La Politique à la Âge de la Défiance. Paris, Seuil.

(1998), Le Peuple Introuvable. Histoire de la Représentation Démocratique en France.

Paris, Gallimard.

SAWARD, Michael. (2009), "Authorisation and Authenticity: Representation and the Unelected". The Journal of Political Philosophy, vol. 17, no 1, pp. 1-22.

SCHUMPETER, Joseph. (1942), Capitalism, Socialism and Democracy. New York, Harper. SEN, Amartya. (1992), Inequality Reexamined. Cambridge, Harvard University Press.

STONE SWEET, Alec. (2000), Governing with Judges. Oxford, Oxford University Press. e THATCHER, Mark. (2003), The Politics of Delegation. London, Routledge.

STR $\varnothing$ M, Kaare. (2000), "Delegation and Accountability in Parliamentary Democracies". European Journal of Political Research, vol. 37, no 3, pp. 261-289.

, MÜLLER, Wolfgang e BERGMAN, Torbjörn. (2003), Delegation and Accountability in Parliamentary Democracies. Oxford, Oxford University Press.

UNGER, Roberto Mangabeira. (2007), The Self Awakened. Pragmatism Unbound. Cambridge, Harvard University Press.

URBINATI, Nadia. (2006), Representative Democracy: Principles and Genealogy. Chicago, Chicago University Press.

WARREN, Mark e PEARSE, H. (eds.). (2008), Designing Deliberative Democracy: The British Columbia Citizens' Assembly. Cambridge, Cambridge University Press.

WILlIAMS, Melissa S. (2000), Voice, Trust, and Memory. Princeton, Princeton University Press.

YOUNG, Iris Marion. (2002), Inclusion and Democracy. Oxford, Oxford University Press. . (2006) [1989], "Polity and Group Difference: A Critique of the Ideal of Universal Citizenship", in R. Goodin e P. Pettit (eds.), Contemporary Political Philosophy. Blackwell Publishing, Oxford, pp. 248-263. 


\section{ABSTRACT \\ Pragmatic Democracy: The Premises of an Empirically Oriented Normative Theory}

This article's working hypothesis is that contemporary reflection on democracy should not be limited to the false dichotomy between representation on the one hand and participation and decision-making on the other. Within the scope of dialectically analyzing democracy, the article contends that numerous possibilities remain to be explored, even from the normative point of view, given the reluctance of democratic theory to draw on empirical reality to test its premises, expand its concepts, revalidate its meanings, and broaden its horizons. The article thus proposes to introduce in broad strokes "pragmatic democracy", a normative concept serving as an analytical tool to approach the contingency and complexity of contemporary democracy and its institutions.

Key words: democracy; representation; participation; pragmatism

\section{RÉSUMÉ \\ Démocratie Pragmatique: Présupposés d'une Théorie Normative Empiriquement Orientée}

Dans cet article, on part de la prémisse que la réflexion contemporaine sur la démocratie ne doit pas buter sur la fausse dichotomie entre d'un côté, représentation, et de l'autre, participation et délibération. En souhaitant penser dialectiquement ce qu'est la démocratie, on suggère qu'il y a beaucoup de possibilités encore inexploitées dans une optique de norme, face à la réticence de la théorie démocratique à se servir de l'apport de la réalité empirique afin d'évaluer ses prémisses, d'élargir ses concepts et horizons et de revalider ses significations. Ainsi, on propose l'introduction des grandes lignes de la "démocratie pragmatique", un concept normatif qui peut servir d'outil dans l'analyse de la contingence et de la complexité qui marquent la démocratie contemporaine et ses institutions.

Mots-clé: démocratie; représentation; participation; pragmatisme 